\title{
The situation of agricultural education in the Hungarian language in Romania
}

\author{
Dezső Vencel \\ Apor Péter Szakközépiskola, Kézdivásárhely, Románia \\ dezsovencel@gmail.com
}

SUMMARY

\begin{abstract}
Our objective was to analyse the situation of Hungarian language agricultural higher education in Romania. Our analyses have been focused mainly on Kovászna county. Following the evaluation of the characteristics of the county, we assessed the situation of Hungarian language higher education in Romania. History is considered important, because Hungarian language agricultural higher education goes back to the 1860s. The best solution for measuring the current reputation was the completion of questionnaires, which was done by 140 randomly selected people in Kovászna county. Following the evaluation and analysis of the questionnaires we found that local agricultural education, plant production and livestock farming are important activities for the locals. However, it is sure that even if they are satisfied with the education, they consider continuous development very important, since it would be a major help for the employment and subsistence of fresh graduates in Kovászna county.
\end{abstract}

Keywords: Kovászna county, agriculture, Hungarian, higher education, questionnaire

\section{INTRODUCTION}

The diverse geographic situation of Székely Land allowed the creation of various economic activities in terms of different geographic area types: mountains, plateaus and lowlands. The diverse terrain is mostly mountains where tourism and livestock farming (sheep, cattle) are popular activities, but it also includes open areas which are advantageous for agriculture. The less exploited agricultural sector is that of mushrooms and forest fruits, which could provide a considerable income for the region. The East Carpathians cover almost the entire area of Kovászna and Hargita counties (Györffy, 1941; Anderca et al., 1991; Bözödi, 1997, Bodor, 2003; Balog et al., 2008).

Székely Land which consists of Hargita, Kovászna and Maros counties and has 1.2 million inhabitants is an average area of Romania in terms of development. The economic performance ability of the area within the new economic field changed only because its indexes represent average performance in Romanian comparison system according to Bözödi (2002).

Kovászna county is situated in the heart of Romania. It is adjacent to Bacau, Vrancea and Buzau counties from the east, Brasso from the west and Hargita county from the north. The county with its total area of $3705 \mathrm{~km}^{2}$ is the third smallest county of the country (Csosz, 1996). If Kovászna county is known from anything in the world, it is mainly because its tourism. Still, tourism as an economic sector does not really exploit these potentials. Currently, tourism activities have a contribution of $1 \%$ to the business turnover realised within the county (Bagi, 1979). Still, rural tourism, agricultural and ecotourism have a significant development potential within the area. (Sandu, 1998).

University education is continuously being extended in the area, university branches have been established in almost every larger city of the region. Multilingual education takes place at the universities. Therefore, currently the Babes-Bolyai University of Kolozsvár (Cluj) the Economic Academy of Bucarest, the Lucian
Blaga University of Szeben and the Hungarian Gábor Dénes College have local faculties (Horváth, 2003).

\section{MATERIAL AND METHODS}

A questionnaire-based survey has been carried out about the situation and future of the agricultural education and agriculture of Kovászna county between 2010 and 2012. The completion of the questionnaires has been carried out anonymously with random selection. The questionnaire includes 25 questions which can be classified into three groups in terms of topics. The first 17 questions refer to the personal data of the respondent, such as gender, age, education level, etc. The second group of questions (18-21) deals with the local agricultural education. The third part is for respondents who have participated or already are participating in basic or adult agricultural education. Most of the questions are closed questions, where the answers can be selected from predefined options. For most of the questions a single option of the predefined answers can be selected. In the case of the rest of the questions, multiple options could be selected. The last question of the questionnaire is an open question, where the respondents could describe their opinions, comments about the asked questions and the agricultural topic. 140 questionnaires have been completed which have been evaluated with Microsoft Excel and SPSS for Windows software.

\section{RESULTS AND DISCISSION}

The first higher education institution of Transylvania was the Economic College of Kolozsmonostor, which started its operation in October 1869. The education period was 3 years. Admission did not require a high school final exam, but 6 high school classes had to be completed by the applicants. The model farm had a territory of 755 acres, which was hired by the Hungarian state from the church of Kolozsmonostor for 30 years. In 1903 Monostor has been linked to Kolozsvár, therefore a name change became necessary; the institution was 
named Economic Institute of Kolozsvár. Three years later the Ministry granted university rank to the institution, therefore it continued its operation as the Economic Academy of Kolozsvár. At this time the students received the degree of 'certified farmer' upon graduation. In 1914 the institution has been closed.

However, Hungarian language agricultural education has not been terminated entirely in Transylvania, the traditional churches established agricultural schools with a two year education period.

Following the Vienna Award the course of Hungarian agricultural education in Transylvania took another turn. The Romanian language college moved to Temesvár, therefore the first three then four year (1942) higher education in Kolozsvár was re-launched. Following World War II, the Romanian institution returned from Temesvár and Hungarian education is terminated once again.

However, in 1948 the education law resulted in positive changes, the Hungarian department of the Agricultural Academy has been established. The department had its own dean, administration, faculty and a considerably high amount of students. After 1955, Hungarian language education in Kolozsvár stopped again.

Correspondence education started in remote faculties of Hungarian universities in Csíkszereda (1992) and Nyárádszereda (1993).
In 2001, the Sapienta Hungarian University of Transylvania (SHUT) has been established, which was an independent institution in Romania, where the continuous operation and development is financed by the Hungarian government.

$7^{\text {th }}$ October, 2001, two Faculties started education in Csíkszereda and Marosvásárhely. Following that a constant extension started within the organisation of SHUT. The university made contact with other Hungarian universities. They signed their first cooperation agreement with the University of Debrecen in 2003. SHUT is continuously increasing, as does its number of students and lecturers and it organises Hungarian language agricultural higher education in Transylvania together with other organisations.

The aim of our analyses is the estimation of the situation of Hungarian language higher education in Romania from the aspect of external observers and the people participating in education as well.

Completion of the questionnaires has been carried out in multiple settlements of Kovászna county, therefore we could have a more realistic picture about the opinion of people. The questionnaire has been completed by 140 Kovászna inhabitants. In terms of gender distribution we found that $71.4 \%$ of the respondents are males (100 people) and $28.6 \%$ are females (40). The youngest people among the respondents are 16 years old, while the oldest

\begin{tabular}{|c|c|c|c|c|c|c|}
\hline \multicolumn{7}{|c|}{ Age and gender distribution of respondents } \\
\hline & Total & Age distribution (\%) & Male (no.) & Male $(\%)$ & Female (no.) & Female $(\%)$ \\
\hline $21-30$ years & 17 & 12.1 & 13 & 76.5 & 4 & 23.5 \\
\hline $31-40$ years & 19 & 13.6 & 8 & 42.1 & 11 & 57.9 \\
\hline $61-70$ years & 2 & 1.4 & 2 & 100.0 & 0 & 0.0 \\
\hline Above 71 years & 2 & 1.4 & 2 & 100.0 & 0 & 0.0 \\
\hline Did not respond & 4 & 2.9 & 3 & 75.0 & 1 & 25.0 \\
\hline Total & 140 & 100.0 & 100 & 71.4 & 40 & 28.6 \\
\hline
\end{tabular}

is an 82 years old person. $39 \%$ of the respondents belong to the 16-20 year age group (55 people). Detailed age and gender distribution is shown by table 1 .

Besides age, educational level belongs to the personal questions as well. Seven categories have been provided for the respondents so they could select their highest finished education level. 3 of the 140 respondents have not finished eight-grade yet. Finished eight-grade has the highest proportion (36.4\%); it is followed by technical school $(27.9 \%)$ and high school graduation (16.4\%). Only one respondent had a doctoral degree. Detailed information about education level is shown by table 2 .

The questionnaire also included questions related to the settlement the respondents currently live (village or city) and/or work in. 32 of the 140 respondents $(22.9 \%)$ live in a city, 108 of them (77.1\%) live in a village. Two of the people living in a city work in one of the nearby villages, 29 of them work in a city. 52 of the people living in a village also work in a village and 54 of the work in a city. Three of the respondents (one living in a city and two living in a village) did not indicate their working location.
Distribution of highest education level

\begin{tabular}{lcc}
\hline Finished education level & $\begin{array}{c}\text { Distribution } \\
\text { (no.) }\end{array}$ & $\begin{array}{c}\text { Distribution } \\
(\%)\end{array}$ \\
\hline Did not finish eight-grade & 3 & 2.1 \\
Eight-grade & 51 & 36.4 \\
Technical school & 39 & 27.9 \\
High school graduation & 23 & 16.4 \\
Technical college & 8 & 5.7 \\
College, university & 11 & 7.9 \\
PhD degree & 1 & 0.7 \\
Did not respond & 4 & 2.9 \\
Total & 140 & 100.0 \\
\hline
\end{tabular}

The personal questions included inquiries about the current employment of the respondents. 56 people $(40.0 \%)$ were students, $30(21.4 \%)$ farmers, $32(22.9 \%)$ employees, $10(7.1 \%)$ sole entrepreneurs, $2(1.4 \%)$ occasional workers, and 6 respondents $(4.3 \%)$ were 
unemployed. 4 of the respondents $(2.9 \%)$ chose the 'other' option from the available answers. Not only the type of employment was asked but the area of expertise as well. Eight fields have been determined as optional answers. $53 \%$ of the people not studying work in agricultural production, $6 \%$ in industrial production, $3 \%$ are craftsmen, $8 \%$ works in the servicing sector, $7 \%$ in public education, $1 \%$ are health workers and $22 \%$ choose 'other'. Agriculture is the main employment for 34 people of the 140 respondents, for 62 it is a complementary activity, for 14 it is a hobby and 17 people do not deal with agriculture at all. The next question was about the exact field of agriculture the given respondent might be working in. $51.4 \%$ deals with field cultivation, $22.9 \%$ with livestock farming, and $15.0 \%$ with horticulture (table 3 ).

Table 3.

Distribution of people dealing with agriculture among the different fields

\begin{tabular}{lcc}
\hline Field of expertise within agriculture & $\begin{array}{c}\text { Distribution } \\
\text { (no.) }\end{array}$ & $\begin{array}{c}\text { Distribution } \\
(\%)\end{array}$ \\
\hline Field cultivation & 72 & 51.4 \\
Horticulture & 21 & 15.0 \\
Plantation farming & 4 & 2.9 \\
Livestock farming & 32 & 22.9 \\
Forestry & 2 & 1.4 \\
Processing of animal products & 2 & 1.4 \\
Processing of plant products & 3 & 2.1 \\
Agricultural machinery service & 7 & 5.0 \\
Rural tourism & 4 & 2.9 \\
\hline
\end{tabular}

Only $25.7 \%$ of the respondents declare to be having any kind of agricultural qualification. Therefore, $74.3 \%$ do not have any. Among the people that have agricultural qualification, it is related to cultivation for $5 \%$, to livestock farming for $3.5 \%$ to tourism for $3.5 \%$, to agricultural machinery for $6.4 \%$, and $3.5 \%$ have other qualifications. $57.1 \%$ responded positively to the question asking if having a qualification helps subsistence.

The above questions dealt with personal data and education. The next some questions is about the agriculture of Kovászna county. In the case of the question about the agricultural characteristics of Kovászna county, 7 predefined options were available to choose from based on the opinion of the respondent. The highest proportion (44.3\%) belongs to the option which says that the residents utilise the available potential of the area properly. Detailed answers are shown by table 4.

The second question was about the leading agricultural sector in Kovászna county. Nine sectors were provided to choose from (table 5). Following the agricultural situation and the determination of the leading sector we asked the respondents about what could further improve the county in their opinion. The respondents indicated field cultivation in the highest proportion as a potential development potential (47.1\%). Livestock farming (34.3\%) and agriculture-related rural tourism $(18.6 \%)$ were also important development courses in the opinion of the respondents. Further development possibilities and the distribution of the answers are shown by table 6 .

The opinion of respondents about the agricultural situation of Kovászna county

\begin{tabular}{lcr}
\hline & Distribution (no.) & Distribution (\%) \\
\hline Better than the country average & 34 & 24.3 \\
Worse than the country average & 15 & 10.7 \\
Better than the region average & 6 & 4.3 \\
Worse than the region average & 17 & 12.1 \\
They are utilised well considering the possibilities & 62 & 44.3 \\
They are not utilised well & 23 & 16.4 \\
They not ensure competitive agricultural production & 26 & 18.6 \\
\hline
\end{tabular}

Table 5 .

Distribution of the leading agricultural sectors based on the opinion of the respondents

\begin{tabular}{lcc}
\hline & $\begin{array}{c}\text { Distribution } \\
\text { (no.) }\end{array}$ & $\begin{array}{c}\text { Distribution } \\
(\%)\end{array}$ \\
\hline Field cultivation & 59 & 42.1 \\
Horticulture & 9 & 6.4 \\
Plantation farming & 6 & 4.3 \\
Livestock farming & 37 & 26.4 \\
Forestry/lumber processing & 14 & 10.0 \\
Processing of animal products & 11 & 7.9 \\
Processing of plant products & 1 & 0.7 \\
Agricultural machinery service & 10 & 7.1 \\
Rural tourism related to agriculture & 6 & 4.3 \\
\hline
\end{tabular}

Table 6.

Possible development courses of Kovászna county and their distribution in proportion of the respondents

\begin{tabular}{lcc}
\hline & $\begin{array}{c}\text { Distribution } \\
\text { (no.) }\end{array}$ & $\begin{array}{c}\text { Distribution } \\
(\%)\end{array}$ \\
\hline Field cultivation & 66 & 47.1 \\
Horticulture & 16 & 11.4 \\
Plantation farming & 16 & 11.4 \\
Livestock farming & 48 & 34.3 \\
Forestry/lumber processing & 15 & 10.7 \\
Processing of animal products & 11 & 7.9 \\
Processing of plant products & 13 & 9.3 \\
Agricultural machinery service & 5 & 3.6 \\
Rural tourism related to agriculture & 26 & 18.6 \\
Tourism based on any local attribute & 9 & 6.4 \\
\hline
\end{tabular}


In the questionnaire we not only asked the respondents about their opinion of agriculture in Kovászna county, their thoughts about local agricultural education were also important for us. $31.4 \%$ of the respondents answered this question. Nine possible options were provided. The opinions showed that the level of agricultural education in Kovászna county is lower than before the change of regime, but it was better even before the EU accession. These two options have a combined $50 \%$ proportion of the answers. There were large differences among the remaining seven options based on the answers of the other 22 respondents. Detailed distribution of the answers is shown by table 7 .

Distribution of opinions about agricultural education in Kovászna county

\begin{tabular}{lcc}
\hline & Distribution (no.) & Distribution (\%) \\
\hline The level is below the agricultural education before the change of regime & 13 & 9.3 \\
The level is below the agricultural education before the EU accession & 9 & 6.4 \\
The level is below the average Romanian agricultural education & 4 & 2.9 \\
The level is below the average Hungarian agricultural education & 6 & 4.3 \\
The level is above the agricultural education before the change of regime & 3 & 2.1 \\
The level is above the agricultural education before the EU accession & 1 & 0.7 \\
The level is above the average Romanian agricultural education & 6 & 4.3 \\
The level is above the average Hungarian agricultural education & 1 & 0.7 \\
It did not change, it has the same level as before & 1 & 0.7 \\
\hline
\end{tabular}

In the next question we asked about the relationship of agricultural education and Kovászna county. The answers for the question whether local agricultural education improves the agriculture of the county were relatively alike. 64 of 84 respondents claimed that local agricultural education improves agriculture. According to 17 respondents, it did not improve it and 3 people think that the two have no relation at all.

Following that, we looked for the potentially most successful field of expertise out of 5 predefined ones. Based on the questionnaires we found that the two most successful fields of expertise are cultivation $(17.1 \%)$ and livestock farming $(15.7 \%)$, which are followed by rural tourism $(5.7 \%)$. Horticulture and fruit production have not been indicated by any of the respondents.

We considered important to ask, which fields of expertise within agricultural education should be improved in order to improve the situation of the county and to aid the employment of fresh graduates. According to the respondents, although livestock farming (36.4\%) and cultivation (32.1\%) are successful, they need to be further improved to be competitive. Beyond these two fields the horticultural sector $(15.7 \%)$ and the processing of agricultural products (14.3\%) should be improved as well. Tourism (7.9\%), agricultural and EU administration (3.6\%) and economics (2.9\%) are also considered important, but their proportion is far behind the agricultural sectors.

\section{CONCLUSION}

Based on the analysed opinions and answers we drew the conclusion that agricultural education on Kovászna county is important for the county and the resident families. They consider cultivation and livestock farming the most important, and they see a great opportunity in their development in the future. More than $70 \%$ of the respondents deal with agriculture, therefore the opinion of the residents is very important. However, not only these two areas should be developed, but rural tourism as well which is closely related to agriculture, therefore it would support the subsistence of locals and facilitate the development and modernisation of the area. Within this, the processing of agricultural products is an important task, because it would create an opportunity to produce products with higher added value; this would support the effective operation of agricultural producers and the subsistence of families.

\section{REFERENCES}

Anderca, C.-Sambotin, L.-Otiman, P. (1991): Forme şi structuri de proprietate în agricultura României. Studiu USAB. Timişoara. 44.

Bagi J. (1979): Gabonaipari gazdálkodás és termékforgalmazás. Mezőgazdasági Könyvkiadó. Budapest. 24-25.

Balog A.-Bálint J.-Kovács L.-Kentelky E.-Jakab S.-Nyárádi I.Theisz R. (2008): Az erdélyi magyar agrároktatás múltja, jelene, jövője. Editura Nico. Targu Mures. 13-45.

Bodor Gy. (2003): A székely nemzetségi szervezet (Nobile Officium). Pallas-Akadémia Kiadó. Csíkszereda. 142.

Bözödi Gy. (1997): Székely bánja. Mentor Kiadó. Marosvásárhely. 312
Bözödi Gy. (2002) Székely századok. Történelmi tanulmányok. (Bibliotheca Transsylvanica). Pallas-Akadémia Könyvkiadó. Csíkszereda. 352

Csosz, I. (1996): Agroturismul montan. Ed. Mirton. Timisoara. 25. Györffy Gy. (1941): A székelyek eredete és településük története. [In: Mályusz E. (szerk.) Erdély és népei.] Budapest.

Horváth Gy. (2003): Székelyföld. Dialog Campus Kiadó. BudapestPécs. 127.

Sandu, D. (1998): Rural community poverty in Romania. Targets for poverty alleviation by Romania Social Development Fund. Raport. BM. 24. 